Print ISSN: 2288-4637 / Online ISSN 2288-4645

doi:10.13106/jafeb.2020.vol7.no10.035

\title{
Effect of Liquidity, Profitability, Leverage, and Firm Size on Dividend Policy
}

\author{
Jozef R. PATTIRUHU ${ }^{1}$, Maartje PAAIS ${ }^{2}$
}

Received: July 18, 2020 Revised: August 23, 2020 Accepted: September 03, 2020

\begin{abstract}
This study aims to investigate the relationship between the variables of Current Ratio (CR), Return-on-Equity (ROE), Return-on-Assets (ROA), Debt-to-Equity Ratio (DER), and Firm Size (FS) on Dividend Policy (DP) in real estate and property companies listed on the Indonesia Stock Exchange in the period 2016-2019, looking at nine real estate companies in Indonesia. The research methodology uses an explanatory analysis approach and linear regression. Based on the eligibility and homogeneity of the data, the number of sample companies selected was nine companies. The company's financial statement data derived from primary data obtained on the Indonesia Stock Exchange, such as current ratio (CR), return-on-equity (ROE), return-on-assets (ROA), debt-to-equity ratio (DER) and firm size and dividend policy variables. The data analysis procedure is first to transform financial data from the original ratio data into interval data and, then, transform it to ordinal data. Furthermore, the validity and reliability process are ignored because the data is primary. Finally, regression testing is part of the hypothesis testing stage. The results of this study showed that the CR, ROE, and firm size had no positive and significant effect on dividend policy. In contrast, DER and ROA have a positive and significant impact on dividend policy.
\end{abstract}

Keywords: Liquidity, Profitability, Leverage, Firm Size, Dividend Policy

JEL Classification Code: G11, G12, G18, G32, R32

\section{Introduction}

The capital market has an essential role in meeting the business world's capital needs to continue to exist, develop, and be sustainable. Through capital market activities, companies can obtain funds from investors to finance operational activities and company expansion (Przychodzen $\&$ Przychodzen, 2013). One of the industries in the capital market are companies engaged in the property and real estate sector. Opportunities in the real estate and property industry in Indonesia show excellent performance. This is

${ }^{1}$ First Author and Corresponding Author. Associate Professor, Faculty of Economics, Department of Financial Management, Universitas Pattimura, Ambon, Indonesia [Postal Address: Ot Pattimaipauw Street, Wainitu Nusaniwe, Ambon City, Maluku, Indonesia] Email: pattiruhu.jozef@gmail.com

${ }^{2}$ Associate Professor, Faculty of Economics, Department of Management, Universitas Kristen Indonesia Maluku, Ambon, Indonesia. Email: maartjepaais80@gmail.com

(c) Copyright: The Author(s)

This is an Open Access article distributed under the terms of the Creative Commons Attribution Non-Commercial License (https://creativecommons.org/licenses/by-nc/4.0/) which permits unrestricted non-commercial use, distribution, and reproduction in any medium, provided the original work is properly cited. an opportunity to remember the pace of housing growth in Indonesia, which is still high. Indonesian Real Estate Data (REI) shows that the increasing population and the middle class make this sector continue to stretch. Demand for housing is keeps rising, which is an opportunity for investors (Katadata.co.id, 2018). Housing development also received support from the government, ranging from infrastructure development, public transportation, to regulations that facilitate the property business in Indonesia. The business prospect in the property industry environment is motivated by the increase of the population in Indonesia, which continues to grow every year. In the country, the population is around 250 million, with a birth rate of 1.2 percent per year. Half of the total population of Indonesia is in the productive age, which is 30 years old. Therefore, investors' opportunity to invest their capital in the housing sector is tremendous to guarantee profits. The business capital invested in the real estate sector seems like a business that has no end and continues to be sustainable. The latest data in the first quarter of 2020 revealed that the commercial property price indexes of several significant provinces in Indonesia experienced a rapid increase (see Figure 1). 


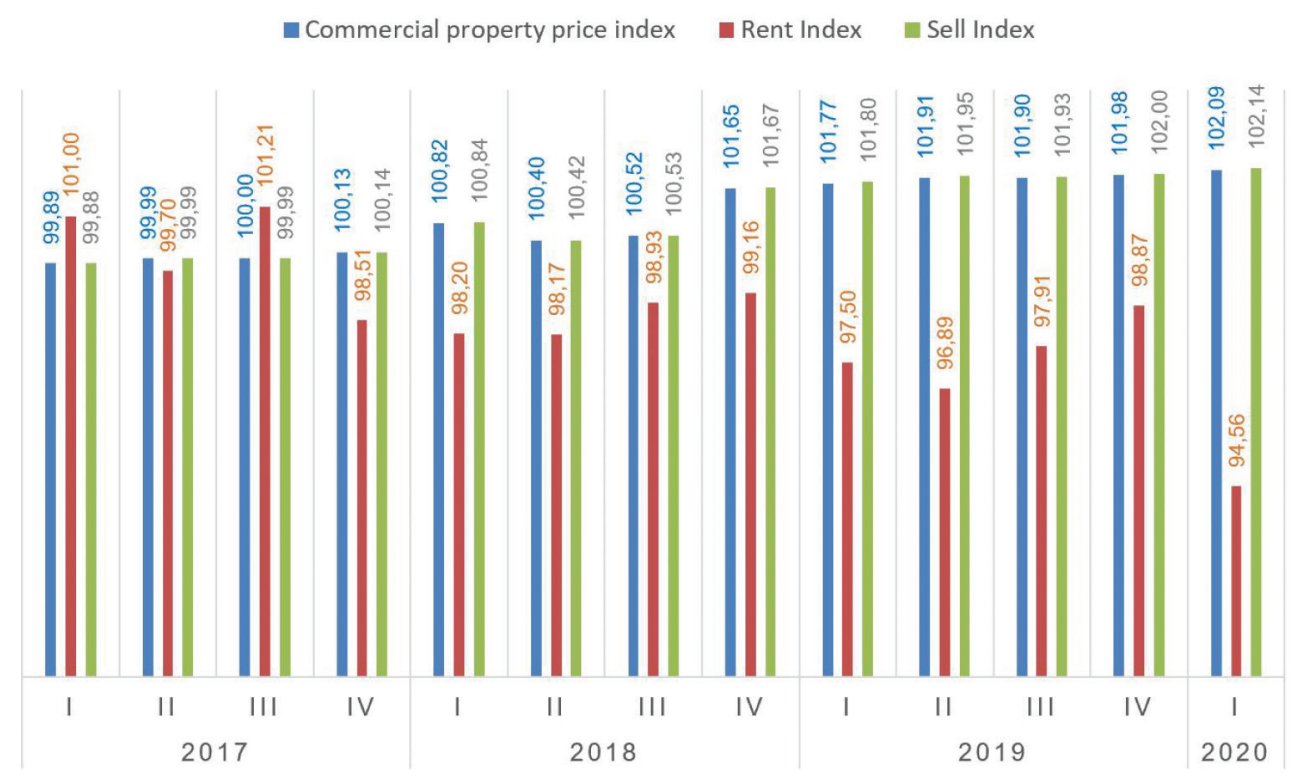

Figure 1: Indonesia Property Price Index (www.bi.go.id, 2020).

However, after experiencing a slowdown in 2019, several economists predict 2020 there will see improvements in the performance of the property sector to boost the domestic economy. This happened thanks to the relaxation of the macroprudential policy from Bank Indonesia at the end of 2019. In Indonesia's property sector in the last three years (2017-2019), the value of growth was insignificant. Moreover, in 2019 there was a general elections, which made investors in the property and real estate sector adopt a wait-and-see posture. Therefore, the Loan-to-Value (LTV) relaxation conducted by Bank Indonesia in 2019 was expected to provide positive sentiment so that the property sector is again excited. One of the objectives of the LTV/ FTV (loan-to-value/financial-to-value) policy is to maintain the financial system stability and mitigate systemic risk occurring from rising property prices (www.bi.go.id, 2019). The LTV/FTV policy is also a macroprudential instrument to encourage a balanced and quality banking intermediary function in supporting economic growth while maintaining financial system stability. However, this macroprudential policy instrument is counter-cyclical (fiscal and monetary easing policies to spur economic growth) that can be adjusted to changes in economic and financial conditions. One strategy in carrying out counter-cyclical procedures is to regulate dividend policies.

In investing their capital, investors will carefully consider which company the money will be spent in. For this reason, investors need a company's financial statements to invest their capital to see future profits and further company development to determine the company's working conditions or financial condition. Dividend policy is an integral part of the company's funding decisions. It is a choice whether profits earned by the company at the end of the year will be distributed to shareholders as dividends or the benefits will be retained to increase capital for investment financing in the future (Miller \& Rock, 1985; Kato et al., 2002; Hoang et al., 2020).

Some previous studies have demonstrated several important points that influence dividend policy, namely, liquidity, leverage, and probability (e.g., Ben-Zion \& Shalit, 1975; Tahir et al., 2020; Jiang et al., 2017), where they agreed that these factors play an essential role in influencing dividend policy; however, some critical factors that also affect the dividend policy is company size. The fact is that not a few companies decide not to distribute their dividends in the financial reporting period. For example, the case in Indonesia is the dividend policy carried out by Bumi Serpong Damai Ltd with the BSDE stock code. In 2011, the company decided not to distribute dividends, but in 2012 the company distributed dividends amounting to $20.4 \%$ of its profit. From 2013 to 2015, the company continued to significantly reduce the amount of dividend distribution, which amounted to $9.75 \%$ in $2013,7.21 \%$ in 2014 and $5.21 \%$ in 2015 . The magnitude of the policy of distributing dividends each year was based on the company's conditions - for example, the company decided to reduce profits for 2015 to $4.51 \%$.

The policy was chosen because it will carry out company expansion activities by undertaking corporate capital expenditure, such as acquiring reserve land and developing previously-owned reserves. Also, decreasing the amount of net income obtained will also affect the dividends distributed during the year. Whereas the distribution of profits can 
reduce the impact arising from agency costs between the management and potential investors, investors expect the maximum return, while the company's management is considering holding some of its profits to be reinvested to improve company performance. So that the right and fair dividend distribution policy is needed for both parties, then another factor determining dividend policy is profitability (Oladipupo \& Okafor, 2013). Profitability is the result obtained through management efforts towards funds invested by owners and investors. The higher the profit or profitability earned by the company, the higher the dividend distributed.

However, a compelling case is also shown by the phenomenon experienced by the property development company owned by Sinarmas Group, Bumi Serpong Damai Ltd (BSD), which distributed a dividend of ID96.23 billion out of the 2015 profit; it showed a decrease in dividend distribution by $66.67 \%$ from the previous year, which was IDR288.7 billion. This was due to a reduction in Bumi Serpong Damai Ltd (BSD) in 2015 by $43.98 \%$ or to IDR2. 14 trillion compared to the previous year (IDR3.82 trillion). Once the importance of dividend policy for many parties is stated, so the factors that influence the dividend policy based on financial information published by companies need to be identified, and liquidity is one of the determinants of dividend policy. Therefore, this study objectively measures and investigates the involvement of liquidity, leverage, firm size, and probability factors on dividend policy.

\section{Literature Review}

In signaling theory, an action will produce a reaction. Included in this are stakeholder reactions related to financial conditions. Signaling in financial statements is an action taken by company management that provides instructions for investors about future management of the company's prospects (Ullah, 2020; BliegeBird et al., 2005). Companies with favorable prospects will try to avoid the sale of shares and seek every new capital needed by other means, including the use of debt that exceeds the target of a healthy capital structure. Companies with unfavorable prospects will tend to sell their shares (Zhang \& Wiersema, 2009; Certo et al., 2001). The announcement of issuance of shares by a company is generally a signal that management views the company's prospect as bleak. If a company offers to sell new shares more often than is usual, then the share price will decrease, because issuing new shares means giving negative signals that can then suppress the stock price and the company's bright prospects. Dividend signaling theory emphasizes the importance of information released by companies on investment decisions of parties outside the company. Data is an essential element for investors and business people because it mainly presents information, notes, or pictures for the past, present, and future conditions for the survival of a company and its effects. Investors in the capital market need complete, relevant, accurate, and timely information as an analytical tool for making investment decisions (Jahanzeb, 2012).

Dividends are profits from companies that are distributed to shareholders. Dividend policy is an integral part of a company's funding decision, which will be distributed to shareholders and reinvested or retained in the company (Hoang et al., 2020; Nam, 2019). If the company chooses to distribute profits as dividends, it will reduce retained earnings and subsequently reduce total internal or internal financing sources. In this study, dividend policy is measured by the Dividend Payout Ratio (DPR). The reason why the Dividend Payout Ratio was chosen is that it can better describe opportunistic managerial behavior, namely, by looking at how much profit is distributed to shareholders as dividends and how much is retained by the company (Garrett \& Priestley, 2000). Lintner (1956) was the first to investigate the relationship between firm size and dividend policy. He revealed a reciprocal relationship between firm size and the amount of dividends given to investors (Aivazian et al., 2003; Tahir \& Mushtaq, 2016). In line with Lintner, Brav et al. (2008) revealed that the factors that influence dividend policy include earning over time and disclosing information to sustainable shareholders, including risk factors and corporate financial expenditure. The same opinion was shared by Zhang et al. (2020), which states that the current ratio is one of the measurement tools in determining dividends based on current liabilities calculations.

The financial manager's task is to determine the optimal dividend policy to maintain the company's value. Factors that influence the dividend's size to be paid by the company to shareholders include solvency position (Alvarez \& Virtanen, 2006; Hadi, 2019), company liquidity position (Malik et al., 2016; Jiang et al., 2017), the need to pay off debt (Jensen et al., 1992), debt expansion plan (Fama \& French, 2002), and investment opportunities (Smith Jr \& Watts, 1992; Masulis \& Trueman, 1988). Another factor in measuring the dividend payout ratio's ability is also looking at the company's profitability ratio (Nguyen \& Nguyen, 2020; Tahir \& Mushtaq, 2016). Profitability ratios include ROE (Return-on-Equity), where the higher the ROE ratio, the more efficient the company is using its capital to generate a net profit. Next is leverage. In this study, the leverage ratio used is debt-to-equity ratio (DER), which is the ratio that compares total debt with total equity. Furthermore, there are growth factors and company size (Rehman \& Takumi, 2012). Debt-to-equity ratio factor has a positive and significant effect on the company's dividend policy (Rehman \& Takumi, 2012; Gill et al., 2010). Growth is a company asset where assets are used for the company's operational activities. The more rapid the growth of a company in generating profits, the higher the expenditure needed to finance its growth. It must limit dividends to save funds in 
the company for investment growth. Dempsey et al. (2019) revealed a relationship between the company's growth rate and its ability to implement a dividend policy. It was then clarified in research by Fajaria and Isnalita (2018), which states that firm growth, firm value, and firm size moderate the company's dividend policy.

Therefore, to illustrate the effect of liquidity, profitability, and leverage on dividend policy with company size, a conceptual framework is created. The shape of the theoretical framework can be illustrated, as illustrated in Figure 2.

Based on prior research literature review and then some hypothesis in this study are:

H1: Current ratio, return-on-equity, return-on-assets, debt-to-equity ratio have a positive and significant effect on dividend policy.

H2: Current ratio, which gives a positive and significant influence on dividend policy is accompanied by a high debtto-equity ratio

\section{Research Methods and Materials}

\subsection{Data Criteria}

The research method approach is explanatory. This approach was chosen because it highlights the causal relationship between variables in testing hypotheses formulated previously in the literature review section. The type of data collected is panel data. The research subjects are property, real estate, and construction companies listed on the Indonesia Stock Exchange in the period 2016-2019. Based on the eligibility and homogeneity of the data, the number of sample companies selected was nine companies. The company's financial statement data derived from primary data obtained on the Indonesia Stock Exchange, such as current ratio (CR), return-on-equity (ROE), return-on-assets (ROA), debt-to-equity ratio (DER) and firm size and dividend policy variables. Data are illustrated in Table 1 . The study period was December 2019-February 2020.

\subsection{Measurement}

The data analysis method in this study uses regression analysis. The stages in measuring and testing the instrument go through several procedures such as:

- Procedure 1: transform data so that the data components become even data. This step analyzes the use of SPSS using data transformation from ratio data to scale data interval. Then, the component values are transformed into ordinal data according to the interval class.

- Procedure 2: testing the hypotheses through direct and moderation testing with a significance level $<0.50$. On checking using primary data, the validity and reliability tests are ignored.

\section{Results and Discussion}

The first procedure performed is transforming ratio data into interval data. In the process of transforming class data the interval is divided into five interval clusters $(1=$ very high, $2=$ high, 3 = moderate, $4=$ low, $5=$ very low). Data transformation aims to find the point of normality data. The results of the transformation of variable data interval current ratio $(\mathrm{CR})=0.66-15.85$ with a range $=3.032$, return-onequity $(\mathrm{ROE})=0.03-0.292$ with range $=0.052$, return-onassets $(\mathrm{ROA})=1.07-4.004$ with range $=0.586$, debt-toequity ratio $(\mathrm{DER})=0.130-2.825$ with range $=0.1495$, firm size $=0.260-38.58$ with range $=7.66$, dividend policy $=$ $0.03-0.52$ with range $=0.098$. The results of data normality testing using the Kolmogorov-Smirnov method $=0.922>$ 0.05 which can be interpreted that the data are normally distributed (see Table 1).

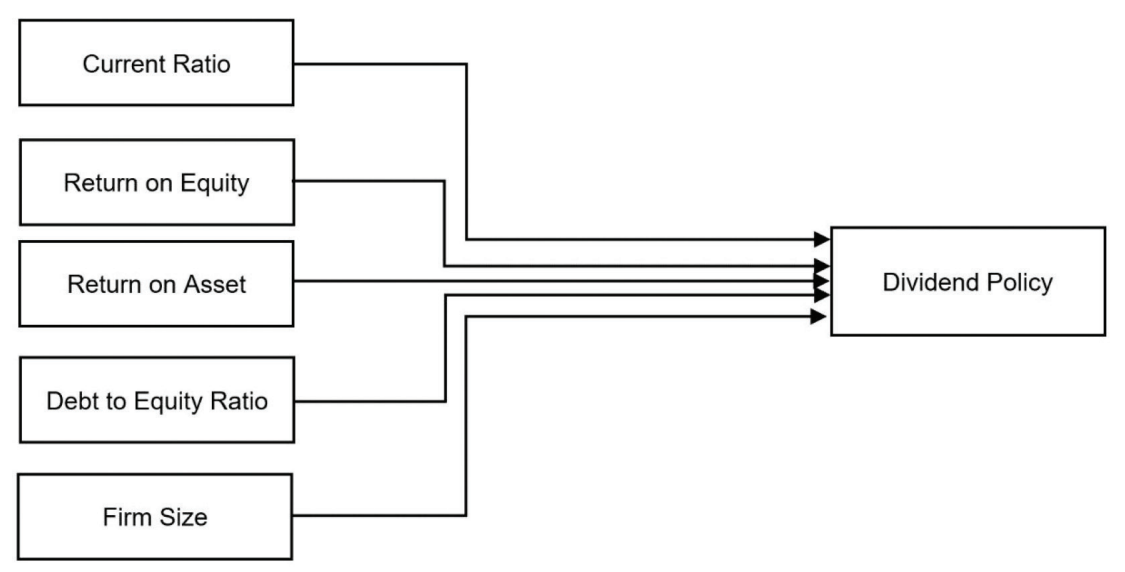

Figure 2: Conceptual Framework 
Table 1: Data

\begin{tabular}{|c|c|c|c|c|c|c|c|}
\hline Firm and Code & Years & $\begin{array}{c}\text { Current } \\
\text { Ratio }\end{array}$ & $\begin{array}{l}\text { Return on } \\
\text { Equity }\end{array}$ & $\begin{array}{c}\text { Return on } \\
\text { Asset }\end{array}$ & $\begin{array}{l}\text { Debt to } \\
\text { Equity } \\
\text { Ratio }\end{array}$ & Firm Size & $\begin{array}{l}\text { Dividend } \\
\text { Policy }\end{array}$ \\
\hline \multirow{4}{*}{$\begin{array}{l}\text { Agung Podomoro } \\
\text { Land. Ltd (APLN) }\end{array}$} & 2016 & 1,68 & 0,05 & 1,77 & 1,74 & 19,72 & 0,14 \\
\hline & 2017 & 1,83 & 0,04 & 1,75 & 1,80 & 23,76 & 0,14 \\
\hline & 2018 & 1,39 & 0,05 & 1,66 & 1,71 & 24,51 & 0,14 \\
\hline & 2019 & 1,07 & 0,04 & 2,86 & 1,58 & 25,73 & 0,18 \\
\hline \multirow{4}{*}{$\begin{array}{l}\text { Alam Sutera } \\
\text { Realty. Ltd } \\
\text { (ASRI) }\end{array}$} & 2016 & 0,75 & 0,06 & 2,05 & 1,71 & 14,42 & 0,33 \\
\hline & 2017 & 1,14 & 0,07 & 1,59 & 1,66 & 16,19 & 0,13 \\
\hline & 2018 & 0,72 & 0,04 & 2,76 & 1,83 & 18,03 & 0,23 \\
\hline & 2019 & 0,97 & 0,03 & 1,74 & 1,81 & 20,10 & 0,27 \\
\hline \multirow{4}{*}{$\begin{array}{l}\text { Bekasi Fajar } \\
\text { Industrial Estate. } \\
\text { Ltd (BEST) }\end{array}$} & 2016 & 2,53 & 0,22 & 2,51 & 0,35 & 3,32 & 0,03 \\
\hline & 2017 & 2,26 & 0,11 & 1,19 & 0,28 & 3,61 & 0,06 \\
\hline & 2018 & 3,92 & 0,05 & 2,82 & 0,52 & 4,64 & 0,06 \\
\hline & 2019 & 3,29 & 0,07 & 2,61 & 0,54 & 5,25 & 0,06 \\
\hline \multirow{4}{*}{$\begin{array}{l}\text { Bumi Serpong } \\
\text { Damai. Ltd } \\
\text { (BSDE) }\end{array}$} & 2016 & 2,67 & 0,13 & 1,82 & 0,35 & 22,61 & 0,09 \\
\hline & 2017 & 2,18 & 0,14 & 2,59 & 0,23 & 28,25 & 0,07 \\
\hline & 2018 & 2,73 & 0,07 & 2,66 & 0,35 & 35,96 & 0,04 \\
\hline & 2019 & 2,94 & 0,05 & 1,11 & 0,30 & 38,31 & 0,07 \\
\hline \multirow{4}{*}{$\begin{array}{l}\text { Ciputra } \\
\text { Development. Ltd } \\
\text { (CTRA) }\end{array}$} & 2016 & 1,40 & 0,10 & 1,64 & 0,48 & 20,25 & 0,20 \\
\hline & 2017 & 1,43 & 0,08 & 1,14 & 0,53 & 23,52 & 0,21 \\
\hline & 2018 & 1,52 & 0,07 & 2,93 & 0,63 & 26,27 & 0,10 \\
\hline & 2019 & 1,88 & 0,04 & 2,42 & 0,73 & 28,93 & 0,10 \\
\hline \multirow{4}{*}{$\begin{array}{l}\text { Duta Anggada } \\
\text { Realty. Ltd } \\
\text { (DART) }\end{array}$} & 2016 & 2,09 & 0,04 & 1,58 & 0,48 & 4,77 & 0,49 \\
\hline & 2017 & 1,89 & 0,11 & 1,23 & 0,44 & 5,11 & 0,21 \\
\hline & 2018 & 0,73 & 0,05 & 1,55 & 0,52 & 5,74 & 0,30 \\
\hline & 2019 & 0,66 & 0,05 & 1,07 & 0,54 & 6,07 & 0,30 \\
\hline \multirow{4}{*}{$\begin{array}{l}\text { Intiland } \\
\text { Development. Ltd } \\
\text { (DILD) }\end{array}$} & 2016 & 0,71 & 0,05 & 1,71 & 0,26 & 7,54 & 0,15 \\
\hline & 2017 & 0,77 & 0,05 & 2,81 & 0,37 & 9,05 & 0,12 \\
\hline & 2018 & 0,89 & 0,04 & 2,65 & 0,53 & 10,28 & 0,12 \\
\hline & 2019 & 0,98 & 0,03 & 2,14 & 0,64 & 11,84 & 0,25 \\
\hline \multirow{4}{*}{$\begin{array}{l}\text { Duta Pertiwi. Ltd } \\
\text { (DUTI) }\end{array}$} & 2016 & 10,17 & 0,26 & 2,69 & 0,15 & 0,26 & 0,12 \\
\hline & 2017 & 12,22 & 0,05 & 2,03 & 0,14 & 0,27 & 0,32 \\
\hline & 2018 & 13,35 & 0,04 & 2,03 & 0,14 & 0,27 & 0,15 \\
\hline & 2019 & 15,16 & 0,03 & 1,79 & 0,13 & 0,29 & 0,16 \\
\hline \multirow{4}{*}{$\begin{array}{l}\text { Megapolitan } \\
\text { Development. Ltd } \\
\text { (EMDE) }\end{array}$} & 2016 & 1,84 & 0,04 & 1,26 & 0,69 & 0,94 & 0,09 \\
\hline & 2017 & 1,62 & 0,04 & 1,33 & 0,96 & 1,18 & 0,07 \\
\hline & 2018 & 1,49 & 0,05 & 1,47 & 0,81 & 1,22 & 0,12 \\
\hline & 2019 & 2,06 & 0,05 & 2,93 & 0,98 & 1,36 & 0,22 \\
\hline
\end{tabular}


Table 2: Regression Result

\begin{tabular}{|c|c|c|c|c|c|c|}
\hline \multirow{2}{*}{ Model } & \multicolumn{2}{|c|}{ Unstandardized Coefficients } & \multirow{2}{*}{$\begin{array}{c}\begin{array}{c}\text { Standardized } \\
\text { Coefficients }\end{array} \\
\text { Beta } \\
\end{array}$} & \multirow{2}{*}{$\mathbf{t}$} & \multirow{2}{*}{ sig } & \multirow{2}{*}{ Conclusion } \\
\hline & B & Std. Error & & & & \\
\hline Dividend & 0.668 & 0.179 & & 3.846 & $0.000<0.01$ & - \\
\hline Current Ratio & -0.007 & 0.048 & -0.007 & -0.147 & $0.884>0.05$ & Not Support \\
\hline Return on Equity & -0.259 & 0.235 & -0.196 & -1.105 & $0.278>0.05$ & Not Support \\
\hline Return on Asset & 0.372 & 0.049 & 0.342 & 7.613 & $0.000<0.01$ & Support \\
\hline $\begin{array}{l}\text { Debt to equity } \\
\text { Ratio }\end{array}$ & 0.137 & 0.045 & 0.139 & 3.029 & $0.003<0.01$ & Support \\
\hline Firm Size & 0.084 & 0.051 & 0.082 & 1.637 & $0.102>0.05$ & Not Support \\
\hline
\end{tabular}

Table 2 explains the results of hypothesis testing, where the partial test (F-square) shows a coefficient value of 2,806 and significant at $<0.01$. With the coefficient of determination (R-square) of 0.481 , it can be concluded that the relationship between the variable current ratio (CR), return-on-equity (ROE), return-on-assets (ROA), debt-to-equity ratio (DER), and firm size and dividend policy is $48.1 \%$. Table 2 explains the results of hypothesis testing, where the partial test (F-square) shows a coefficient value of 2,806 and significant $<0.01$. With the coefficient of determination (R-square) of 0.481 , it can be concluded that the relationship between the variable current ratio $(\mathrm{CR})$, return-on-equity (ROE), returnon-assets (ROA), debt-to-equity ratio (DER), firm size and dividend policy is $48.1 \%$.

The current ratio is the ratio of total current debt (shortterm debt) divided by current assets (cash/bank, accounts receivable, securities, and inventories), which indicates that the company can cover all its short-term debt using existing current assets. The results of our study found that the current ratio (CR) does not have a significant positive relationship with the dividend policy. This means that no matter how big or small, a change in current ratio (CR) does not affect the company's dividend policy level. Ideally, the higher the ratio of current assets and current debt, the better the opportunity and the company's ability to pay for its security, including dividends. However, in the case of companies operating in the real estate and property sector in Indonesia, this does not apply. On the other hand, this condition provides two main types of images about companies in the real estate and property industry sectors, namely: 1) if the position of the $\mathrm{CR}$ value is too high, it can be assumed that the company is less able to use its current assets or smooth debt efficiently. It was causing problems in managing working capital because the ideal ratio of the current ratio is 1.50 or $150 \%$. In some examples, the acquisition of the current ratio value of the number of sample companies shows that almost all companies in the financial statement period are above 1.50 .
However, the high value of the current ratio in the eyes of investors also leads to assumption that a high value of the current ratio provides good conditions for a company to meet its debt payment obligations. 2) No positive effect and the significance of the current ratio to the dividend policy signals that property and real estate companies during the financial statement period hold profits for investors. The profits can be reused as a working company capital in the next financial period. If observed strictly, large firm size does not guarantee that the dividend policy given to investors is also large. This is illustrated by some companies with firm size above the ratio of 10 , which tends to play in the dividend distribution policy ratio between $0.06-0.12$. Inversely proportional to companies with a smaller firm size where the courage to provide dividends to investors is also relatively hard, namely, above the ratio of 0.10 . These conditions can impact investor interest in the future, especially for investors who prefer dividends at the end of the financial statement period.

Furthermore, the relationship between return-on-assets (ROA) and dividend policy shows a positive and significant effect. The considerable asset value assumes that, in the performance of property and real estate companies in Indonesia, the use of working capital and also financing from investors is used to increase the company's current ratio and total assets to make financial statements look healthy. Furthermore, in the case of a seemingly small dividend policy, it can also be assumed that corporate dividends are more likely to use the asset dividend method or dividend distribution to investors through the distribution of company assets to its investors. This can be seen where the dominant real estate and property companies in Indonesia tend to have a small dividend policy, only a few companies that decide to divide dividends in a reasonably large ratio (above 0.10 ) at the end of the 2019 financial period.

Theoretical and managerial implications. Being an essential concern of scholars in the field of financial science, the role and management strategy of the value of the current 
ratio, return-on-equity and size of the company does not always have a significant influence on a company's dividend policy. Of course, a significant concern is that firm size should be in line with its debt-to-equity ratio component. In the eyes of business people, of course, paying attention to investors is a corporate obligation, especially for companies that dominantly involve investor funds to achieve the company's competitive advantage. Such notice is appropriate, given the company's progress, especially for companies that go public, and requires clarity of information and transparency of financial statements for investors to attract further investor interest. In terms of investors, knowledge in the field of investment also becomes essential, especially for short-term investors. They are very concerned about dividends, both liquid dividends and dividend distribution in assets. Such knowledge is necessary so that investors become aware of and understand where they will invest their money. Even though real estate and property companies in Indonesia are quite tempting at a glance because property and real estate are mandatory needs of everyone, firm size capital and financial statements alone are not enough to guarantee that companies investors will provide companies' dividend policy.

\section{Conclusions}

Ideally, large or small dividend policies depend on the needs of the company. Of course, companies that require enormous costs for business development and expansion or pay off all the company debts would want dividends distributed to investors. The distribution of dividends is not always in the form of liquidity. It can be in the form of stocks, dividend scripts or bonds, and property dividends or distribution of dividends in the form of company goods or assets. Indeed, for companies that have been "wellestablished" where the company's performance has reached the top and tends to be stable in terms of profits and asset acquisition, and where the ability to pay a debt is also optimal, then it manages to distribute dividends in the long term. Therefore, it is an essential concern for investors to be more careful in addressing their investment problems. If investors prefer and expect dividends in the form of shortterm liquidity or capital, while investing moderately, of course, they must be able to master information related to the company's dividend policy behavior.

\section{References}

Aivazian, V., Booth, L., \& Cleary, S. (2003). Dividend policy and the organization of capital markets. Journal of Multinational Financial Management, 13(2), 101-121.https://doi.org/10.1016/ S1042-444X(02)00038-5

Alvarez, L. H. R., \& Virtanen, J. (2006). A class of solvable stochastic dividend optimization problems: on the general impact of flexibility on valuation. Economic Theory, 28(2), 373-398. https://doi.org/10.1007/s00199-005-0627-4

Ben-Zion, U., \& Shalit, S. S. (1975). Size, leverage, and dividend record as determinants of equity risk. The Journal of Finance, 30(4), 1015-1026. https://www.jstor.org/stable/2326720

BliegeBird, R., Smith, E., Alvard, M., Chibnik, M., Cronk, L., Giordani, L., Hagen, E., Hammerstein, P., Neiman, F., \& Bird, R. (2005). Signaling theory, strategic interaction, and symbolic capital. Current Anthropology, 46(2), 221-248. https://doi. org/10.1086/427115

Brav, A., Graham, J. R., Harvey, C. R., \& Michaely, R. (2008). Managerial response to the May 2003 dividend tax cut. Financial Management, 37(4), 611-624. https://doi.org/10.1111/j.1755053X.2008.00027.X

Certo, S. T., Daily, C. M., \& Dalton, D. R. (2001). Signaling firm value through board structure: An investigation of initial public offerings. Entrepreneurship Theory and Practice, 26(2), 33-50. https://doi.org/10.1177/104225870102600202

Dempsey, M., Gunasekarage, A., \& Truong, T. T. (2019). The association between dividend payout and firm growth: Australian evidence. Accounting \& Finance, 59(4), 2345-2376. https://doi.org/10.1111/acfi.12361

Fajaria, A. Z., \& Isnalita, N. (2018). The Effect of Profitability, Liquidity, Leverage and Firm Growth of Firm Value with its Dividend Policy as a Moderating Variable. International Journal of Managerial Studies and Research (IJMSR), 6(10), 55-69.

Fama, E. F., \& French, K. R. (2002). Testing Trade-Off and Pecking Order Predictions About Dividends and Debt. Review of Financial Studies, 15(1), 1-33. https://doi.org/10.1093/ $\mathrm{rfs} / 15.1 .1$

Garrett, I., \& Priestley, R. (2000). Dividend behavior and dividend signaling. Journal of Financial and Quantitative Analysis, 35(2), 173-189.https://doi.org/10.2307/2676189

Gill, A., Biger, N., \& Tibrewala, R. (2010). Determinants of dividend payout ratios: evidence from United States. The Open Business Journal, 3(1), 8-14.

Hadi, W. (2019). The effect of own capital rentability, solvability, profitability and liquidity on dividend policy in food and beverage sub sector companies listed on Indonesia Stock Exchange (IDX). The Management Journal of Binaniaga, 4(1), 37-50. https://doi.org/10.33062/mjb.v4i1.352

Hoang, L. X., Dang, D. Q., \& Tran, T. D. (2020). The Role of Overconfident CEO to Dividend Policy in Industrial Enterprises. Journal of Asian Finance, Economics and Business, 7(7), 361-367. https://doi.org/10.13106/jafeb.2020.vol7.no7.361

Jahanzeb, A. (2012). Implication of behavioral finance in investment decision-making process. Information Management and Business Review, 4(10), 532-536.

Jensen, G. R., Solberg, D. P., \& Zorn, T. S. (1992). Simultaneous determination of insider ownership, debt, and dividend policies. Journal of Financial and Quantitative Analysis, 27(2), 247263. https://www.jstor.org/stable/2331370 
Jiang, F., Ma, Y., \& Shi, B. (2017). Stock liquidity and dividend payouts. Journal of Corporate Finance, 42(February), 295314. https://doi.org/10.1016/j.jcorpfin.2016.12.005

Katadata.co.id. (2018). Rapidly Growing Housing Development in Jakarta and 34 Satellite Cities. Retrieved 25 July 2020 from: https://bit.ly/2BT8BSe

Kato, H. K., Loewenstein, U., \& Tsay, W. (2002). Dividend policy, cash flow, and investment in Japan. Pacific-Basin Finance Journal, 10(4), 443-473. https://doi.org/10.1016/S0927538X(02)00068-9

Malik, M. S., Awais, M., \& Khursheed, A. (2016). Impact of liquidity on profitability: A comprehensive case of Pakistan's private banking sector. International Journal of Economics and Finance, 8(3), 69-74. https://doi.org/10.5539/ijef. v8n3p69

Masulis, R. W., \& Trueman, B. (1988). Corporate investment and dividend decisions under differential personal taxation. Journal of Financial and Quantitative Analysis, 23(4), 369-385.https:// doi.org/10.2307/2331077

Miller, M. H., \& Rock, K. (1985). Dividend policy under asymmetric information. The Journal of Finance, 40(4), 1031-1051. https://www.jstor.org/stable/2328393

Nam, H.-J. (2019). The Effect of Earnings Quality on Financial Analysts' Dividend Forecast Accuracy: Evidence from Korea. Journal of Asian Finance, Economics and Business, 6(4), 91-98. https://doi.org/10.13106/jafeb.2019.vol6.no4.91

Nguyen, T. N. L., \& Nguyen, V. C. (2020). The Determinants of Profitability in Listed Enterprises: A Study from Vietnamese Stock Exchange. Journal of Asian Finance, Economics and Business, 7(1), 47-58. https://doi.org/10.13106/jafeb.2020. vol7.no1.47

Oladipupo, A. O., \& Okafor, C. A. (2013). Relative contribution of working capital management to corporate profitability and dividend payout ratio: Evidence from Nigeria. International Journal of Business and Finance Research, 3(2), 11-20. https://doi.org/10.21276/sjebm.2016.3.9.5
Przychodzen, J., \& Przychodzen, W. (2013). Corporate sustainability and shareholder wealth. Journal of Environmental Planning and Management, 56(4), 474-493. https://doi.org/10.1080/096 40568.2012.685927

Rehman, A., \& Takumi, H. (2012). Determinants of dividend payout ratio: Evidence from Karachi Stock Exchange (KSE). Journal of Contemporary Issues in Business Research, 1(1), 20-27.

Smith Jr, C. W., \& Watts, R. L. (1992). The investment opportunity set and corporate financing, dividend, and compensation policies. Journal of Financial Economics, 32(3), 263-292. https://doi.org/10.1016/0304-405X(92)90029-W

Tahir, H., Rahman, M., \& Masri, R. (2020). Do Board Traits Influence Firms' Dividend Payout Policy? Evidence from Malaysia. Journal of Asian Finance, Economics and Business, 7(3), 87-99. https://doi.org/10.13106/jafeb.2020.vol7.no3.87

Tahir, M., \& Mushtaq, M. (2016). Determinants of Dividend Payout: Evidence from listed Oil and Gas Companies of Pakistan. Journal of Asian Finance, Economics and Business, 3(4), 25-37. https://doi.org/10.13106/jafeb.2016.vol3.no4.25

Ullah, B. (2020). Signaling value of quality certification: Financing under asymmetric information. Journal of Multinational Financial Management, 55(June), 100629. https://doi. org/10.1016/j.mulfin.2020.100629

www.bi.go.id. (2020). Residential Property Survey for Primary House. Bank Central Indonesia. Retrieved 18 July 2020, From: https://bit.ly/2EHycP1

www.bi.go.id. (2019). Ratio Loan to Value or Financing to Value. Bank Central Indonesia. Retrieved 18 July 2020, From: https:// bit.ly/3foLCMh

Zhang, Y., \& Wiersema, M. F. (2009). Stock market reaction to CEO certification: The signaling role of CEO background. Strategic Management Journal, 30(7), 693-710.

Zhang, Y., Uchida, K., \& Dong, L. (2020). External financing and earnings management: Evidence from international data. Research in International Business and Finance, 54(December), 101275. https://doi.org/https://doi.org/10.1016/j.ribaf.2020.101275 